Article

\title{
Screening of a Novel Polysaccharide Lyase Family 10 Pectate Lyase from Paenibacillus polymyxa KF-1: Cloning, Expression and Characterization
}

\author{
Yan Zhao ${ }^{1,+}$, Ye Yuan ${ }^{2,+}$, Xinyu Zhang ${ }^{1}$, Yumei Li ${ }^{1}$, Qiang Li ${ }^{1}$, Yifa Zhou ${ }^{2}$ and Juan Gao ${ }^{1, *}$ \\ 1 School of Biological Science and Technology, University of Jinan, Jinan 250022, China; \\ zhaoyan_1994@126.com (Y.Z.); zhangxinyu950512@163.com (X.Z.); mls_liym@ujn.edu.cn (Y.L.); \\ chm_liq@ujn.edu.cn (Q.L.) \\ 2 School of Life Sciences, Northeast Normal University, Changchun 130024, China; \\ yuany268@nenu.edu.cn (Y.Y.); zhouyf383@nenu.edu.cn (Y.Z.) \\ * Correspondence: bio_gaoj@ujn.edu.cn; Tel.: +86-531-8973-6825 \\ + These authors contributed equally to this work.
}

Received: 28 September 2018; Accepted: 25 October 2018; Published: 26 October 2018

\begin{abstract}
Pectate lyase (EC 4.2.2.2) catalyzes the cleavage of $\alpha$-1,4-glycosidic bonds of pectin polymers, and it has potential uses in the textile industry. In this study, a novel pectate lyase belonging to polysaccharide lyase family 10 was screened from the secreted enzyme extract of Paenibacillus polymyxa KF-1 and identified by liquid chromatography-MS/MS. The gene was cloned from P. polymyxa KF-1 genomic DNA and expressed in Escherichia coli. The recombinant enzyme PpPel10a had a predicted Mr of $45.2 \mathrm{kDa}$ and $p \mathrm{I}$ of 9.41. Using polygalacturonic acid (PGA) as substrate, the optimal conditions for PpPel10a reaction were determined to be $50{ }^{\circ} \mathrm{C}$ and $\mathrm{pH} 9.0$, respectively. The $\mathrm{K}_{\mathrm{m}}, \mathrm{v}_{\max }$ and $\mathrm{k}_{\text {cat }}$ values of PpPel10a with PGA as substrate were $0.12 \mathrm{~g} / \mathrm{L}$, $289 \mu \mathrm{mol} / \mathrm{min} / \mathrm{mg}$, and $202.3 \mathrm{~s}^{-1}$, respectively. Recombinant PpPel10a degraded citrus pectin, producing unsaturated mono- and oligogalacturonic acids. PpPel10a reduced the viscosity of PGA, and weight loss of ramie (Boehmeria nivea) fibers was observed after treatment with the enzyme alone $(22.5 \%)$ or the enzyme in combination with alkali $(26.3 \%)$. This enzyme has potential for use in plant fiber processing.
\end{abstract}

Keywords: Paenibacillus polymyxa; pectate lyase; cloning and expression; ramie degumming

\section{Introduction}

Pectin is a heteropolysaccharide mainly composed of $\alpha$-1,4-linked galacturonic acids with different degrees of esterification [1,2]. Pectin is widely present in the cell walls of terrestrial plants and has a wide range of applications in industries such as food, medicine and fine chemicals [1,3]. Recent studies showed that the degradation products of pectin have good physicochemical properties, and wide application prospects as food additives, pharmaceutical molecules, and materials for cosmetics [4,5].

The complete degradation of pectin requires the synergistic work of a series of enzymes, including pectate lyase, pectin methylesterase, and polygalacturonase [2,6]. Pectate lyases (EC 4.2.2.2), also called trans-eliminases, catalyze the cleavage of pectate via a $\beta$-elimination reaction to generate 4,5-unsaturated oligogalacturonates [7,8]. Recently, pectate lyase has received increasing attention because of its potential applications in various industries, such as in the extraction and clarification of fruit juices and wine, scouring of cotton fabric, retting of flax, degumming of ramie fibers, and treatment of pectic wastewater [7].

Ramie (Boehmeria nivea) fibers have wide application potential, and can be used to make clothing fabrics, twines and canvas [9]. The surface of ramie fiber is covered with gum-like 
materials, which limit its application in the textile industry-The gum-like materials must be removed before application. The traditional degumming process is performed by alkaline treatment at high temperature, which damages the fibers and causes environmental pollution. However, the degumming could also be achieved by enzymatic catalysis performed by pectate lyase $[10,11]$. Enzymatic degumming has advantages compared with alkaline degumming because of its high efficiency, mild conditions and environmental compatibility.

According to the $\mathrm{pH}$ at which they show maximal activity, pectate lyases can be divided into acidic and alkaline groups. Alkaline pectate lyases are preferred for degumming ramie since pectin is more soluble in alkaline solution [12]. Alkaline pectate lyases have been isolated from various microbial sources, including bacteria and fungi [13]. The genus Bacillus is one of the main sources of pectic lyase [11,13-16]. In this study, Paenibacillus polymyxa KF-1 (also known as Bacillus polymyxa) was found to exhibit remarkable pectate lyase activity. A pectate lyase was identified from the enzyme extract of P. polymyxa KF-1 and expressed in Escherichia coli. The recombinant enzyme was purified, and its ability to remove the pectin from ramie was explored.

\section{Results and Discussion}

\subsection{Screening of Pectate Lyase from P. polymyxa KF-1 by LC-MS/MS}

Genes encoding pectate lyases have been cloned from Bacillus spp., such as for the pectate lyase from B. tequilensis SV11; PEL168, Apel and rePelB from B. subtilis; BliPelA from B. licheniformis; Bsp165PelA from Bacillus spp. N16-5; Pel-15E from Bacillus spp. strain KSM-P15; and Pel SWU from Bacillus spp. RN1 [13-18]. Here, P. polymyxa exhibited pectin-degradation activity. Using citrus pectin as the substrate, the pectate lyase activity accumulated with prolonged cultivation time, up to $36 \mathrm{~h}$ (Figure S1). These results suggested that P. polymyxa is a good candidate to screen for pectate lyase. The supernatant of $P$. polymyxa KF-1 culture (i.e., the fermentation broth) was purified by ion exchange chromatography performed using an SP Sepharose fast-flow column. Two peaks with pectate lyase activity were observed in the elution profile (Figure 1); the fraction eluted by $0.2 \mathrm{M} \mathrm{NaCl}$ (fraction 12) exhibited the highest pectate lyase activity and was sent for LC-MS/MS analysis. A total of 28 proteins were identified from the faction, including four pectate lyases, one pectin esterase and 23 proteins which were not pectin-degrading enzymes. As shown in Table 1, ten peptides were retrieved and assigned to four pectate lyases, which belonged to PL families 1,3, 9, and 10, respectively, predicted using the CAZy database (http:/ / www.cazy.org/) [19]. The amino acid sequence of the protein with UniProt accession number E3EEN8 (NCBI protein ID WP_013370345.1) was consistent with a PL family 10 pectate lyase. The PL10 enzyme showed the highest intensity in LC-MS/MS analysis (Table 1), which suggested that the enzyme may be a major component of the pectin-degrading enzymes of P. polymyxa KF-1. Only five pectate lyases belonging to PL family 10 have been characterized, including PelA from B. alcalophillus NTT33 [20], Pel-15E from Bacillus spp. strain KSM-P15 [21], PelA from Azospirillum irakense [22], rPelA from Treponema pectinovorum ATCC 33768 [23], and r-PL_D from Xanthomonas campestris ACCC 10048 [24]. Reported PL10 enzymes had different structure from the reported members in PL family 1,3, and 9, and were active at alkaline conditions, which may be potential in textile industry [20-24]. However, the properties especially the substrate specificity of PL10 enzymes are still unclear. The application of PL10 enzymes on ramie degumming have not been studied. Understanding of PL family 10 pectate lyases are needed for their application. Thus, the gene encoding the PL family 10 enzyme from P. polymyxa KF-1 was chosen for cloning and expression in the present study. 


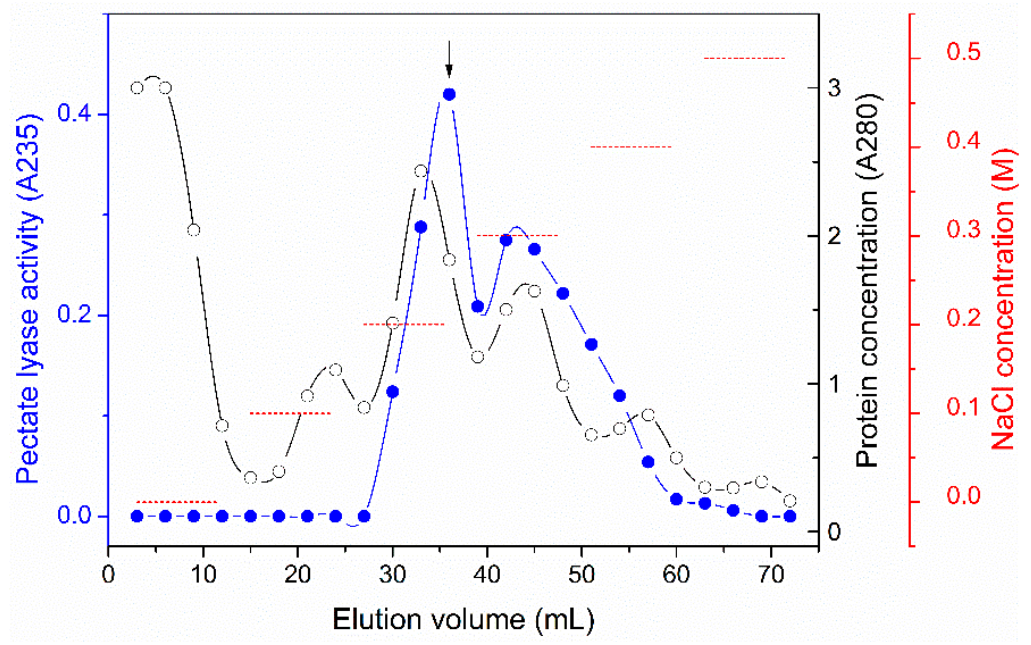

Figure 1. Elution profile of pectate lyase from P. polymyxa KF-1 culture broth by SP Sepharose fast-flow column chromatography. (-๑) Pectate lyase activity (A235); (-○-) protein concentration determined by absorbance at $280 \mathrm{~nm}$ (A280); (-) $\mathrm{NaCl}$ concentration. The arrow indicates the fraction used for LC-MS/MS analysis.

Table 1. Pectate lyases identified from P. polymyxa KF-1 by LC-MS/MS analysis.

\begin{tabular}{|c|c|c|c|c|c|c|c|c|}
\hline Identified Peptide & $\begin{array}{l}\text { Intensity } \\
\left(\times 10^{10}\right)\end{array}$ & $\begin{array}{c}\text { Uniprot } \\
\text { Accession No. }\end{array}$ & $\begin{array}{c}\text { NCBI } \\
\text { Accession No. }\end{array}$ & $\begin{array}{c}\text { Signal } \\
\text { Peptide }^{1}\end{array}$ & $\begin{array}{c}\text { PL } \\
\text { Family }\end{array}$ & $\begin{array}{l}\text { Pfam } \\
\text { Family }\end{array}$ & $\begin{array}{l}\text { Predicted Mw } \\
\quad(\mathrm{kDa})^{2}\end{array}$ & $\begin{array}{c}\text { Predicted } \\
p \mathbf{I}\end{array}$ \\
\hline $\begin{array}{c}\text { QPFDSDILDNTYR } \\
\text { SKDGVELGTFDNEATTTEIR }\end{array}$ & 1.6987 & E3EEN8 & WP_013370345.1 & $1-33$ & 10 & PF09492 & 45.24 & 9.41 \\
\hline EPGTVNITGGGAYHAYDK & & & & & & & & \\
\hline $\begin{array}{c}\text { TVVADPDTLGDGSQK } \\
\text { VNMTLDNSDISNVK } \\
\text { GADGSIQLGDFLK }\end{array}$ & 1.4318 & E3EDF5 & WP_013369567.1 & $1-33$ & 3 & PF03211 & 24.619 & 9.19 \\
\hline $\begin{array}{l}\text { GLAASADDFVSLVPSITR } \\
\text { GSDLIGSGTPSGNIGAR }\end{array}$ & 0.4472 & E3E7F9 & WP_013373703.1 & $1-34$ & 9 & - & 46.988 & 5.50 \\
\hline $\begin{array}{l}\text { VIEIMNDLDLGWNEIPSAAK } \\
\text { VKLELSGSEIK }\end{array}$ & 0.054712 & E0RB75 & WP_013308307.1 & $1-32$ & 1 & PF00544 & 72.777 & 6.18 \\
\hline
\end{tabular}

${ }^{1}$ Signal peptides were predicted using the SignalP 4.1 server (http://www.cbs.dtu.dk/services/SignalP/) [25].

2 Molecular weight and $p \mathrm{I}$ were predicted using the ExPASy Compute $p \mathrm{I} / \mathrm{Mw}$ tool (https://web.expasy.org/ compute_pi/) [26].

\subsection{Gene Cloning and Sequence Analysis}

Analysis of the P. polymyxa genome revealed six genes which were predicted to encode pectate lyases belonging to PL family 1, 3, 9, and 10, respectively. The accession numbers in NCBI for the genes were WP_013372506.1, WP_014599567.1,WP_013369567.1, WP_013370345.1, WP_013373703.1, and WP_013308307.1. Only one PL10 enzyme was retrieved. The gene encoding pectate lyase from P. polymyxa KF-1 was cloned. The open reading frame of $1209 \mathrm{bp}$ encoded a protein of 402 amino acids. The N-terminal 33 amino acids were predicted to be signal peptide by the SignalP 4.1 server. The predicted $\mathrm{Mr} / p \mathrm{I}$ values were $45.24 \mathrm{kDa}$ and $\mathrm{pH}$ 9.41. Generally, pectate lyases are classified into PL families 1, 2, 3, 9, and 10 according to the CAZy database [19]. The amino acid sequence of PpPel10a from P. polymyxa KF-1 showed similarity to the characterized PL family 10 pectate lyases (e.g., AF121904.1, 35\%; JQ723690, 40\%) (Figure 2). Using the family 10 polysaccharide lyase from Cellvibrio cellulosa (PDB ID: 1GXN, identity $=44.79 \%$ ) as a template [27], the structure of PpPel10a was modelled; it displayed a predominantly $\alpha$-helical structure with short $\beta$-strands and irregular coils (Figure $\mathrm{S} 2$ ). The structure of family 10 pectate lyases is different from that of the pectate lyases from PL families 1 , 3 and 9, which have a parallel $\beta$-helix fold [28]. From the amino acid sequence alignment it is deduced that residues D138, N139, R273, E276, R355 and R370 of PpPel10a were responsible for catalysis. 


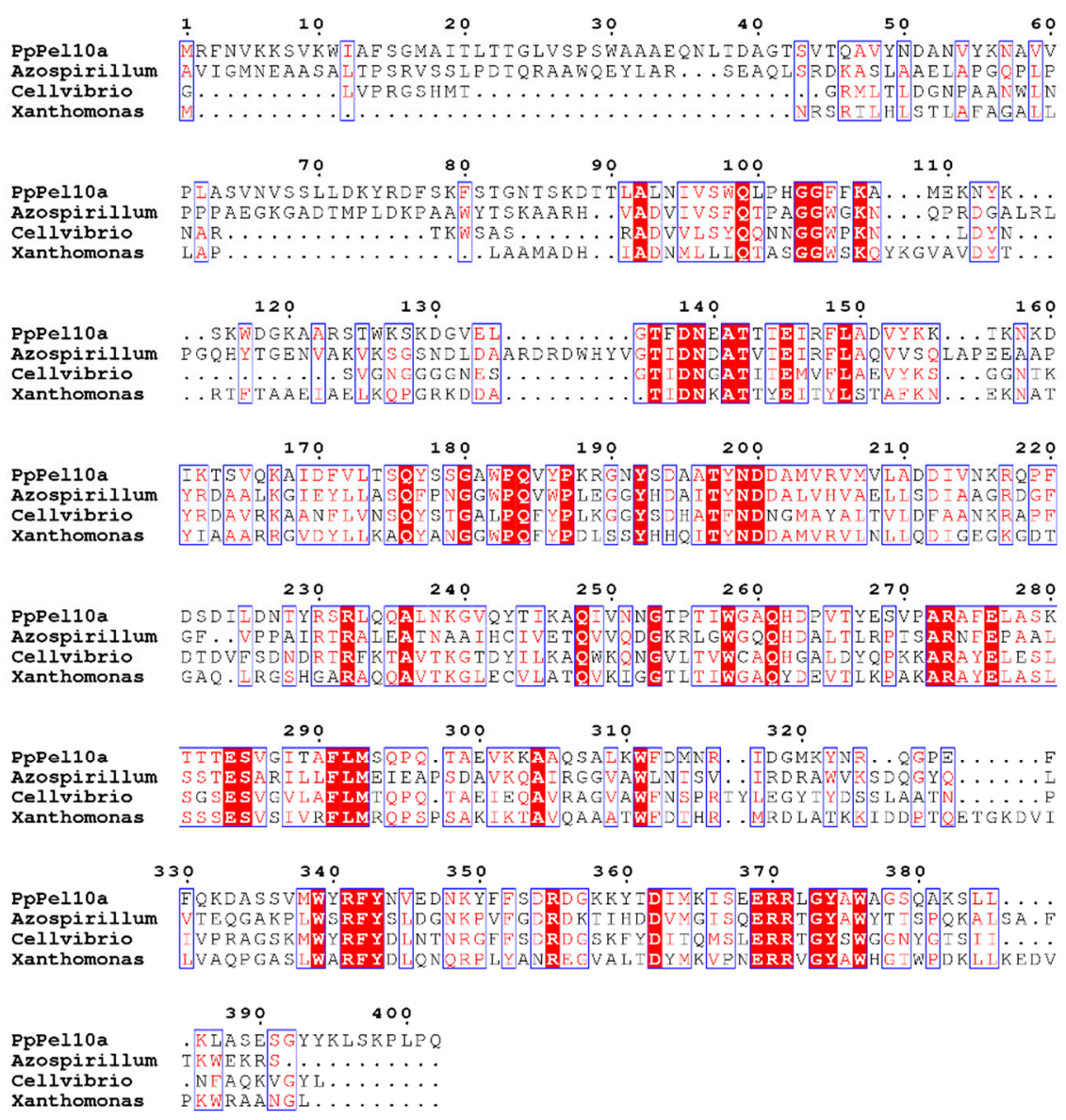

Figure 2. Alignment of amino acid sequence of PpPel10a with those of PL10 family pectate lyases from C. cellulosa (PDB ID: 1GXN), A. irakense (AF121904), and X. campestris (JQ723690).

\subsection{Expression of Recombinant PpPel10a and Enzyme Purification}

The gene encoding the mature pectate lyase PpPel10a was expressed in E. coli BL21 (DE3) cells. After induction with $0.5 \mathrm{mM}$ isopropyl $\beta$-D-1-thiogalactopyranoside (IPTG) at $25^{\circ} \mathrm{C}$ for $10 \mathrm{~h}$, pectate lyase activity was detected mainly in the cell lysate, suggesting the soluble expression of recombinant PpPel10a. Recombinant PpPel10a was purified by Ni-NTA column chromatography, eluted by $50 \mathrm{mM}$ imidazole.

The specific activity of purified enzyme was determined to be $290 \mathrm{U} / \mathrm{mg}$ (Table 2), which was in the range of reported microbial pectate lyases $(45-600 \mathrm{U} / \mathrm{mg})$ [10-12]. Using polygalacturonic acid (PGA) as substrate, the $K_{m}$ and $v_{\max }$ values for the enzyme were determined to be $0.12 \mathrm{~g} / \mathrm{L}$ and $289 \mu \mathrm{mol} / \mathrm{min} / \mathrm{mg}$, respectively. The $\mathrm{k}_{\text {cat }}$ was calculated to be $202.3 \mathrm{~s}^{-1}$.

Table 2. Purification of P. polymyxa KF-1 Pel10a and of recombinant PpPel10a from E. coli.

\begin{tabular}{|c|c|c|c|c|c|c|}
\hline Procedure & $\begin{array}{l}\text { Volume } \\
\text { (mL) }\end{array}$ & $\begin{array}{c}\text { Total Activity } \\
\text { (U) }\end{array}$ & $\begin{array}{l}\text { Total Protein } \\
\text { (mg) }\end{array}$ & $\begin{array}{c}\text { Specific } \\
\text { Activity }(\mathrm{U} / \mathrm{mg})\end{array}$ & $\begin{array}{c}\text { Yield } \\
(\%)\end{array}$ & Purification \\
\hline \multicolumn{7}{|c|}{ Purification } \\
\hline $\begin{array}{c}\text { Fermentation } \\
\text { broth }\end{array}$ & 200 & 2762.5 & 85 & 32.5 & 100.0 & 1.0 \\
\hline $\begin{array}{l}\text { SP Sepharose FF } \\
\text { column }\end{array}$ & 9 & 1066.85 & 9.5 & 112.3 & 38.6 & 3.5 \\
\hline \multicolumn{7}{|c|}{ Heteroexpression } \\
\hline $\begin{array}{c}\text { Crude enzyme } \\
\text { extract }\end{array}$ & 200 & $2,2766.4$ & 216 & 105.4 & 100 & 1.0 \\
\hline Ni-NTA column & 10 & 9889 & 34.1 & 290 & 43.4 & 2.7 \\
\hline
\end{tabular}


The molecular weight of purified recombinant PpPel10a was determined to be approximately 45.2 kDa by SDS-PAGE (Figure 3), which was similar to reported values for PL10 enzymes, such as PelA from B. alcalophillus NTT33 ( 35 kDa), Pel-15E from Bacillus spp. strain KSM-P15 ( 33 kDa), PelA from A. irakense (44.5 kDa), rPelA from T. pectinovorum ATCC $33768(\sim 49 \mathrm{kDa})$, and r-PL D from X. campestris ACCC 10048 ( 38 kDa) [20-24].

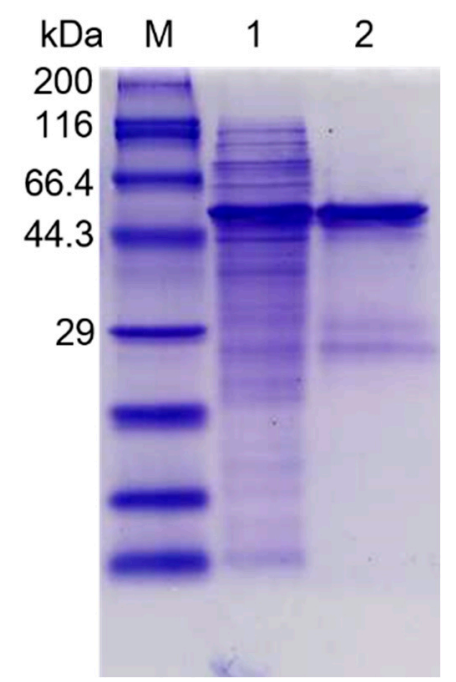

Figure 3. SDS-PAGE analysis of recombinant PpPel10a. M, molecular weight markers; lane 1, supernatant of lysed recombinant E. coli BL21 (DE3) cells carrying plasmid pET28a-pppel10a; lane 2, PpPel10a purified by Ni-NTA column chromatography.

\subsection{Enzymatic Properties of Purified PpPel10a}

The optimal $\mathrm{pH}$ for activity of PpPel10a was determined to be $\mathrm{pH} 9.0$; the enzyme was very active over a wide $\mathrm{pH}$ range ( $\geq 70 \%$ of maximum activity at $\mathrm{pH} 7.0-11.0$ ) (Figure $4 \mathrm{a})$. Alkaline pectate lyases have mainly been cloned from Streptomyces and Bacillus spp. [24]. The optimal pH of PpPel10a was similar to that of Apel from B. subtilis ( $\mathrm{pH}$ 9.0) and r-PL-STR from Streptomyces sp. S27 (pH 9.5), but higher than that of Pel from B. subtilis 168 (pH 8.0) [15,21,29]. PpPel10a showed stability over a wide $\mathrm{pH}$ range; the enzyme retained $>50 \%$ of its initial activity after being held at $\mathrm{pH} 5.0-11.0$ for $24 \mathrm{~h}$ (Figure $4 \mathrm{~b}$ ). The $\mathrm{pH}$ stability of PpPel10a was broader than those of the pectate lyases PEL168 from $B$. subtilis 168 ( $\mathrm{pH} 7.0-9.5$ ), Apel from B. subtilis ( $\mathrm{pH} 7.0-10.0$ ), and r-PL-STR from Streptomyces sp. S27 (pH 7.0-10.0) [13,15,29]. So far, only one PL10 enzyme r-PL D from X. campestris ACCC 10048 was characterized on its $\mathrm{pH}$ stability [24]. $\mathrm{r}$-PL D was stable over a broad $\mathrm{pH}$ range, retaining more than $50 \%$ of its initial activity after incubation at $\mathrm{pH}$ 3.0-12.0. PpPel10a showed similar alkaline-tolerance property as r-PL D, which indicated that alkaline-tolerance may in common among PL10 enzymes. The optimal temperature for activity of PpPel10a was $50{ }^{\circ} \mathrm{C}$ (Figure 4c), which was consistent with that of Apel from B. subtilis $\left(50^{\circ} \mathrm{C}\right)$, but lower than those of PelA from B. licheniformis $14 \mathrm{~A}\left(70{ }^{\circ} \mathrm{C}\right)$, and BacPelA from B. clausii $\left(70{ }^{\circ} \mathrm{C}\right)[14,30]$. PpPel10a was quite stable at $<50{ }^{\circ} \mathrm{C}$, but lost $>50 \%$ of its initial activity after incubation at $60^{\circ} \mathrm{C}$ for $30 \mathrm{~min}$ (Figure $4 \mathrm{~d}$ ). These remarkable alkaline-active, alkali-stable and thermostable properties make PpPel10a an excellent candidate for application in industries requiring alkaline reaction conditions. 

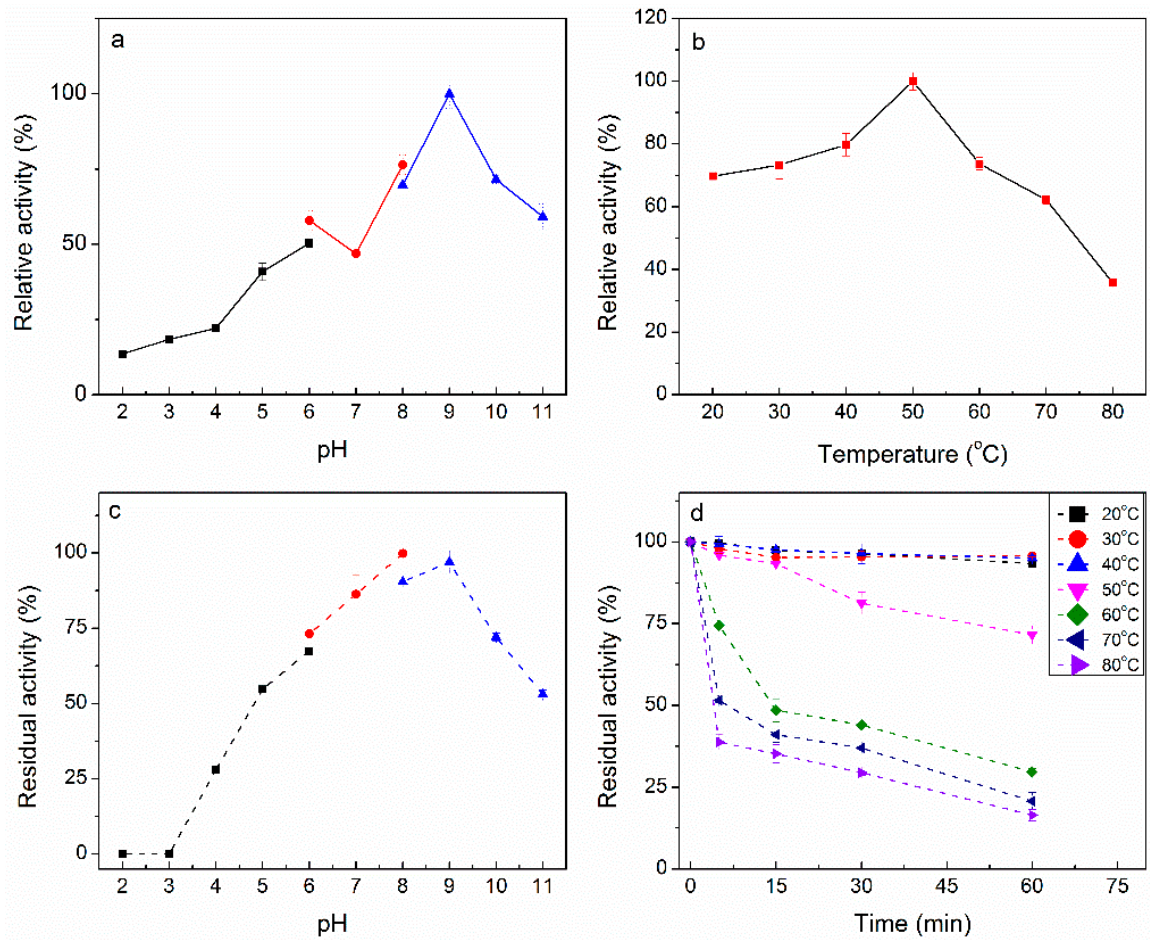

Figure 4. Effect of $\mathrm{pH}$ and temperature on activity and stability of PpPel10a. (a) Optimal reaction $\mathrm{pH}$, (-口-) $\mathrm{pH}$ 2.0-6.0, $50 \mathrm{mM}$ sodium acetate buffer; (-๑) $\mathrm{pH}$ 6.0-8.0, $50 \mathrm{mM}$ phosphate buffer; (-А-) pH 8.0-11.0, $50 \mathrm{mM}$ sodium glycine buffer; (b) optimal reaction temperature; (c) $\mathrm{pH}$ stability,

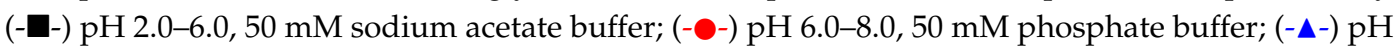
8.0-11.0, 50 mM sodium glycine buffer; (d) thermostability. Pectate lyase activity was measured using polygalacturonic acid (PGA) as substrate.

PpPel10a exhibited remarkable tolerance to metal ions and chemical reagents. As Table 3 shows, $\mathrm{Fe}^{2+}, \mathrm{Co}^{2+}$, SDS and Triton X-100 were strong inhibitors of enzymatic activity at both 1 and $5 \mathrm{mM}$. $\mathrm{Ca}^{2+}$ was reported to be essential for the activity of most pectate lyases (optimal $\mathrm{Ca}^{2+}$ concentration in the range 0.1 to $1.0 \mathrm{mM}$ ). The enzymatic activity of PpPel10a was enhanced by the addition of $\mathrm{Ca}^{2+}$; a dose-dependent effect was observed at $0.1-2.5 \mathrm{mM}$ [31]. The presence of $2.5 \mathrm{mM} \mathrm{Ca}^{2+}$ enhanced the enzyme activity by 1.98 -fold compared with that in the absence of added $\mathrm{Ca}^{2+}$ (Figure 5). Therefore, the addition of $2.5 \mathrm{mM} \mathrm{Ca}^{2+}$ was employed in further experiments. $\mathrm{Mg}^{2+}, \mathrm{Zn}^{2+}$ and $\mathrm{Al}^{3+}$ at $1 \mathrm{mM}$ slightly enhanced the enzymatic activity, while other metal ions and chemicals tested showed no significant effect on the enzymatic activity at 1 or $5 \mathrm{mM}$.

Table 3. Effect of metal ions and chemical reagents on the enzyme activity of PpPel10a.

\begin{tabular}{|c|c|c|}
\hline \multirow{2}{*}{ Metal Ion or Chemical } & \multicolumn{2}{|c|}{ Relative Activity (\%) } \\
\hline & $1 \mathrm{mM}$ & $5 \mathrm{mM}$ \\
\hline $\mathrm{NaCl}$ & $99.3 \pm 1.9$ & $86.7 \pm 3.25$ \\
\hline $\mathrm{KCl}$ & $90.2 \pm 2.0$ & $79.0 \pm 0.55$ \\
\hline $\mathrm{CaCl}_{2}$ & $195.5 \pm 2.65$ & $176.6 \pm 3.2$ \\
\hline $\mathrm{MgCl}_{2}$ & $113.7 \pm 0.55$ & $94.5 \pm 4.65$ \\
\hline $\mathrm{FeSO}_{4}$ & $65.1 \pm 1.5$ & $54.5 \pm 0.65$ \\
\hline EDTA & $89.3 \pm 0.15$ & $63.1 \pm 0.45$ \\
\hline $\mathrm{ZnCl}_{2}$ & $115.2 \pm 0.95$ & $88.0 \pm 1.55$ \\
\hline $\mathrm{AlCl}_{3}$ & $119.6 \pm 0.35$ & $106.1 \pm 3.1$ \\
\hline $\mathrm{CoCl}_{2}$ & $72.2 \pm 3.4$ & $51.4 \pm 2.4$ \\
\hline SDS & $61.7 \pm 1.95$ & $37.7 \pm 0.15$ \\
\hline Tween-20 & $108.0 \pm 1.0$ & $122.5 \pm 0.55$ \\
\hline Triton X-100 & $8.5 \pm 0.75$ & $4.3 \pm 0.15$ \\
\hline
\end{tabular}




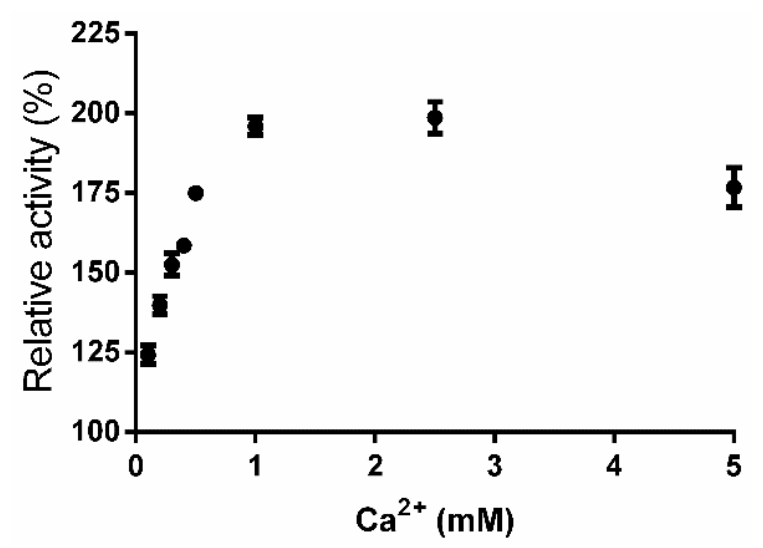

Figure 5. Effect of $\mathrm{Ca}^{2+}$ addition on the activity of PpPel10a.

\subsection{Identification of Products from Citrus Pectin on Degradation by PpPel10a}

High-performance gel permeation chromatography (HPGPC) analysis showed that citrus pectin $(\sim 406,922 \mathrm{Da})$ was degraded to smaller molecular weight species ( 231,899 Da and $\sim 2085 \mathrm{Da})$ by PpPel10a (Figure 6). The oligomers released from citrus pectin by PpPel10a were observed on high-performance anion exchange chromatography (HPAEC) (Figure 7).

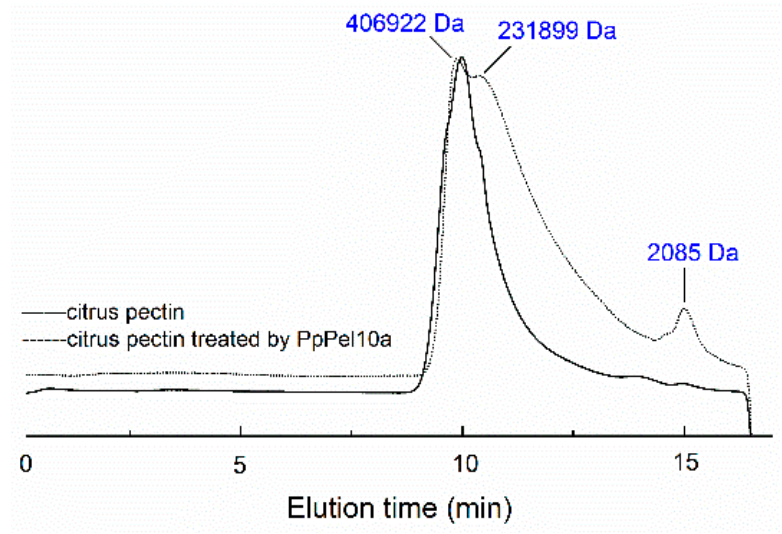

Figure 6. High-performance gel permeation chromatography analysis of the lytic products of citrus pectin produced by PpPel10a. (-) Citrus pectin; (-) lytic products of citrus pectin.

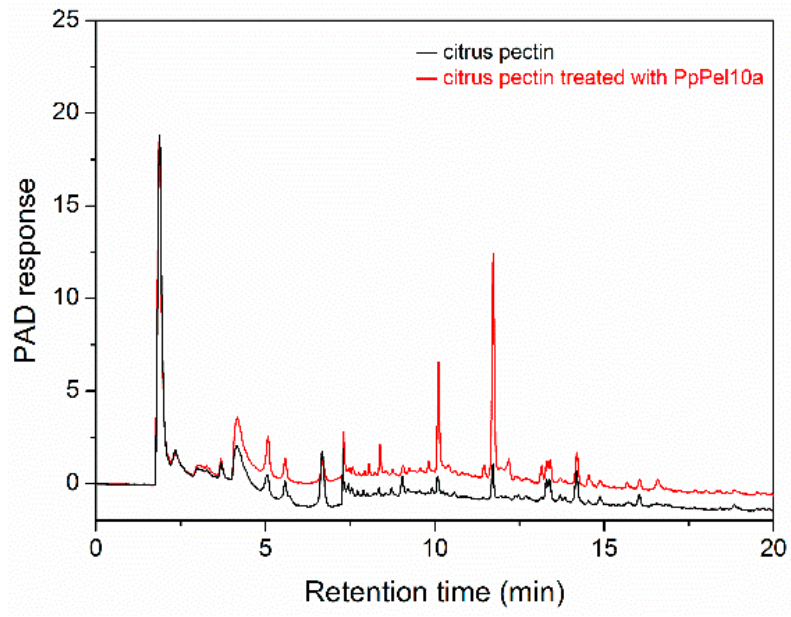

Figure 7. High-performance anion exchange chromatography analysis of the lytic products of citrus pectin produced by PpPel10a. Black line, citrus pectin; red line, lytic products of citrus pectin. 
The oligosaccharides were identified by ESI-MS. Negative ESI-MS gave strong peaks at $m / z$ 175 (unsaturated galacturonic acid, uG1), $m / z 351$ (unsaturated bigalacturonide, uG2), $m / z 527$ (unsaturated trigalacturonide, uG3), $m / z 703$ (unsaturated tetragalacturonide, uG4), and $m / z 879$ (unsaturated pentagalacturonide, uG5) (Figure 8) [16]. The abundance was in the order uG2 > uG3 $>\mathrm{uG} 4>\mathrm{uG} 1>\mathrm{uG} 5$. These results indicate that citrus pectin was degraded by PpPel10a, producing a mixture of 4,5-unsaturated monogalacturonic acid and oligogalacturonic acid, confirming the trans-elimination reaction mechanism of PpPel10a. Generally, exo-acting pectate lyase produces only monomer or dimer, while endo-acting pectate lyase releases larger oligomers [16]. The HPAEC and ESI-MS results showed that $\mathrm{uG} 2$ and $\mathrm{uG} 3$ were the main products released from citrus pectin by PpPel10a, indicating PpPel10a is an endo-acting enzyme. The catalytic behavior of PpPel10a was similar to that of Pel SWU, the PL family 1 endo-acting enzyme from Bacillus spp. RN1, but different from some other reported endo-acting pectate lyases, such as PelA from B. licheniformis 14A and PL from $B$. subtilis, which produced unsaturated oligogalacturonides uG2 and uG3, but not uG1 [14-16]. Only two PL10 enzymes have been reported on their catalytic behavior. PelA from $A$. irakense was an endo-acting pectate lyase, producing multiple unsaturated oligogalacturonates (uG2 to uG9) without the accumulation of uG1 [22]. r-PL D from X. campestris ACCC 10048 was an exo-type pectate lyase, the major product was determined to be $\mathrm{uG} 2$ [24]. Thus, to our knowledge, this is the first report of a PL10 enzyme that can accumulate uG1 from pectin. It is deduced that PL10 enzymes may possess both endo- and exo-acting activities. The catalytic mechanism of PL10 enzymes need to be further studied.

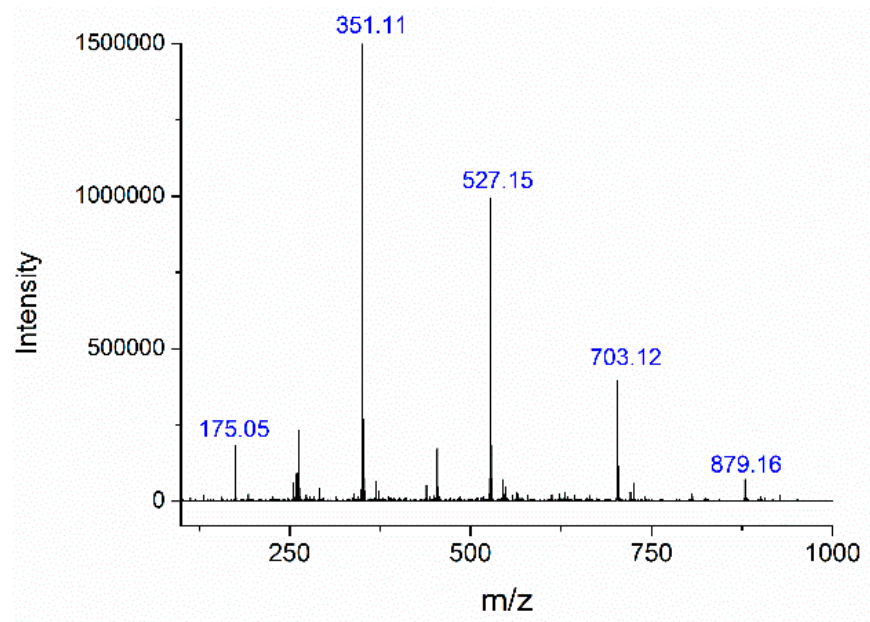

Figure 8. Electrospray ionization-mass spectrometry analysis of the lytic products of citrus pectin produced by PpPel10a.

\subsection{Application of PpPel10a in Viscosity Reduction and Ramie Degumming}

The viscosity of a PGA solution decreased gradually during incubation at $50{ }^{\circ} \mathrm{C}$ for $1 \mathrm{~h}$ on addition of PpPel10a; the relative viscosity was reduced by 33.2\% after $1 \mathrm{~h}$ of incubation (Figure 9). The reducing sugars released from PGA indicated that $<3 \%$ of the galacturonosidic linkages were cleaved, which indicated that PpPel10a acts as an endo-pectate lyase toward PGA.

The ramie degumming effect of PpPel10a was studied. After treatment with $1 \mathrm{U} / \mathrm{mL}$ PpPel10a, $22.5 \pm 0.68 \%$ of the weight of the ramie fibers was lost, whereas $10.1 \pm 0.57 \%$ weight loss was obtained on treatment with $50 \mathrm{mM}$ sodium glycine buffer, $\mathrm{pH}$ 9.0. In combined enzyme and chemical (sodium hydroxide) treatment, the weight loss was $26.3 \pm 0.68 \%$, which was higher than on chemical treatment alone $(0.5 \% w / v \mathrm{NaOH}, 19.9 \pm 0.87 \% ; 1 \% w / v \mathrm{NaOH}, 25.9 \pm 0.65 \%)$. Although the weight losses showed no significant difference between chemical-enzyme combination and $1 \%$ sodium hydroxide, the amount of sodium hydroxide used in the chemical-enzyme combination was $50 \%$ lower, which is better for the environment. 


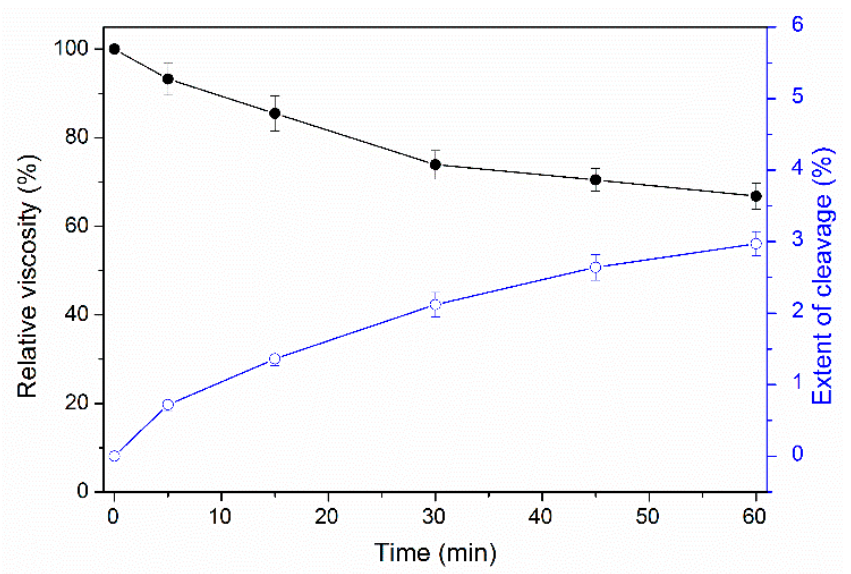

Figure 9. Reduction of PGA viscosity by PpPel10a (-๑-) and galacturonoside bond cleavage (-๑-).

The ramie textile treated by enzyme and enzyme plus chemical became much softer, smoother and whiter compared with that treated with $50 \mathrm{mM}$ sodium glycine buffer $(\mathrm{pH} 9.0)$ or by sodium hydroxide alone, which is favorable for the textile industry. The textiles were observed by scanning electron microscopy (SEM). Figure 10 shows that the enzyme-treated and enzyme-chemical treated samples showed a smoother surface than the control group, which suggested that the gum-like material, i.e., the pectin, was removed.
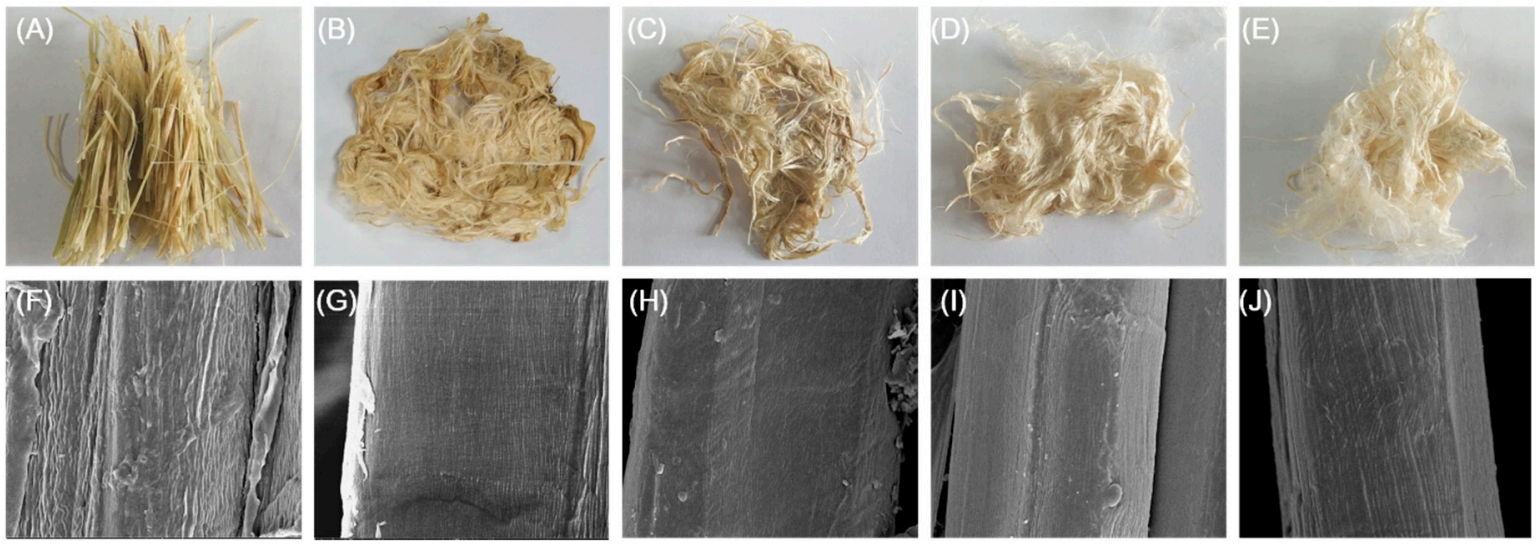

Figure 10. Ramie fibers treated with buffer $(50 \mathrm{mM}$ sodium glycine buffer, $\mathrm{pH}$ 9.0, negative control) $(\mathbf{A}, \mathbf{F})$; chemically $(0.5 \% w / v$ sodium hydroxide $(\mathbf{B}, \mathbf{G})$, or $1 \% w / v$ sodium hydroxide $(\mathbf{C}, \mathbf{H}))$; enzymatically (1 U/mL PpPel10a) (D,I); or with enzyme-chemical combination $(1 \mathrm{U} / \mathrm{mL}$ PpPel10a and $0.5 \% w / v$ sodium hydroxide) (E,J). Images A-E: extrinsic features of ramie fibers; images $\mathbf{F}-\mathbf{J}$ : scanning electron microscopy images of single fibers $(5000 \times)$.

Recently, ramie degumming by some Bacillus spp. alkaline pectate lyases was reported [11,32]. Treatment with pectate lyases from B. pumilus DKS1, B. subtilis 7-3-3, and B. pumilus ATCC7061 resulted in $17 \%, 13.5 \%$ and $23.1 \%$ weight loss, respectively. The degumming efficiency of PpPel10a was higher than those of these pectate lyases. It is reported that the total gum content of ramie fibers is approximately 30-34\% [14]. The reason of the incomplete degumming by PpPel10a may derive from the $\mathrm{pH}$ stability of PpPel10a at extreme alkaline environment. The $\mathrm{pH}$ of $0.5 \% \mathrm{NaOH}$ in $20 \mathrm{~mL}$ of $50 \mathrm{mM}$ sodium glycine buffer ( $\mathrm{pH} 9.0$ ) was determined to be $\sim 12.5$. The activity and stability of PpPel10a in this solution was studied. PpPel10a showed moderate activity at this $\mathrm{pH}, 62.5 \%$ of its activity retained at this $\mathrm{pH}$. After incubated at this $\mathrm{pH}$ for $4 \mathrm{~h}$ at $50{ }^{\circ} \mathrm{C}$, only $45.6 \%$ of its activity was detected. Therefore, the degumming efficiency needs to be further improved by improving the stability of PpPel10a or by using PpPel10a combined with other enzymes. 
Degumming of ramie fibers needs robust pectate lyases that are active and stable at alkaline $\mathrm{pH}$ and moderate temperature [10-12]. PpPel10a may have potential for use in this way because of its alkaline-tolerance and thermostability. In addition, PpPel10a was easily prepared since purification of the enzyme required only one step. Altogether, the enzyme-chemical combination degumming was more environmentally friendly than the traditional chemical degumming process. In the future, the degumming process will be further optimized.

\section{Materials and Methods}

\subsection{Bacterial Strains, Plasmid, and Substrates}

P. polymyxa KF-1 was collected by our laboratory and deposited in the China Center for Type Culture Collection (CCTCC AB 2018146). Escherichia coli DH5 $\alpha$ was used for gene cloning procedures. pET-28a(+) and E. coli BL21 (DE3) cells (Novagen, Madison, MI, USA) were used for recombinant enzyme production. Citrus pectin (P8030) and PGA (P8510) were purchased from Solarbio (Beijing, China).

\subsection{Screening of Pectate Lyase from P. polymyxa KF-1 by LC-MS/MS}

Strain P. polymyxa KF-1 was inoculated into $100 \mathrm{~mL}$ Luria-Bertani (LB) broth and shaken at 200 rpm at $30{ }^{\circ} \mathrm{C}$ for $36 \mathrm{~h}$. After that, the supernatant of culture broth was obtained by centrifugation at $5000 \times g$ and $4{ }^{\circ} \mathrm{C}$ for $10 \mathrm{~min}$. The supernatant was loaded onto a SP Sepharose fast-flow column $(1.5 \times 5 \mathrm{~cm}$; GE Healthcare, Little Chalfont, Buckinghamshire, UK). The column was eluted by a stepwise gradient of $0-0.5 \mathrm{M}$ sodium chloride $(72 \mathrm{~mL})$ in $25 \mathrm{mM}$ Tris- $\mathrm{HCl}, \mathrm{pH}$ 7.5. The pectate lyase activity of each fraction was measured with $0.2 \%$ PGA as substrate. The reaction was carried out in $50 \mathrm{mM}$ sodium glycine buffer ( $\mathrm{pH} 9.0$ ) at $50{ }^{\circ} \mathrm{C}$ for $15 \mathrm{~min}$. The absorbance increase at $235 \mathrm{~nm}$ was recorded. The extinction coefficient of unsaturated galacturonic acid at $235 \mathrm{~nm}$ is $4600 \mathrm{M}^{-1} \mathrm{~cm}^{-1}$ [33]. One unit (U) of activity was defined as the amount of enzyme needed to produce $1 \mu \mathrm{mol} / \mathrm{min}$ unsaturated oligogalacturonide.

The chromatographic fraction with maximum pectate lyase activity was analyzed by Orbitrap Fusion Lumos LC-MS/MS (Thermo Fisher Scientific, Waltham, MA, USA) by Beijing Bio-Tech Pack Technology Company Ltd. (Beijing, China). Briefly, the proteins were in-solution digested by $100 \mathrm{ng} / \mathrm{mL}$ trypsin, the peptides were extracted by a mixture of trifluoroacetic acid/acetonitrile/distilled water (5/50/45, $v / v / v)$, then separated using Acclaim PepMap RSLC C18 column (Thermo Fisher Scientific, Waltham, MA, USA). The separated peptides were analyzed by nanoLC-MS/MS [34]. The data obtained was searched against the UniProt nonredundant protein database for P. polymyxa using Proteome Discoverer 1.4 (Thermo Fisher Scientific, Waltham, MA, USA) [35].

\subsection{Sequence Analysis of PL Family 10 Pectate Lyase}

The peptides identified by LC-MS/MS analysis were analyzed by Protein BLAST (https:/ /blast. ncbi.nlm.nih.gov/Blast.cgi). Amino acid sequence alignment was performed using MEGA version 6.06 (https://www.megasoftware.net/) [36]. Signal peptides were predicted using the SignalP 4.1 Server [25]. A structural model of the pectate lyase PpPel10a was generated using SWISS-MODEL with the family 10 polysaccharide lyase from C. cellulosa (PDB ID: $1 G X N$, identity $=44.79 \%$ ) as the template [28,37].

\subsection{Gene Cloning and Protein Expression}

The pectate lyase gene PpPel10a (NCBI accession number WP_013370345.1) was amplified from genomic DNA of $P$. polymyxa KF-1 using primers 5'-CGGGATCCGAGCAGAATTTGACTGATGC-3' and 5'-CCGCTCGAGTTATTGTGGCAACGGCTTGGACAG-3'. The PCR product was digested with $\mathrm{BamHI}$ and $\mathrm{XhoI}$, and ligated into BamHI/XhoI-digested pET-28a(+). The ligation product was transformed into E. coli DH5 $\alpha$ cells and the recombinant plasmid pET-28a-PpPel10a obtained was used to transform E. coli BL21 (DE3) cells [38]. The transformant was cultured in $200 \mathrm{~mL}$ LB medium 
supplemented with $30 \mu \mathrm{g} / \mathrm{mL}$ kanamycin [13]. Protein induction was initiated by the addition of $0.5 \mathrm{mM}$ IPTG when the optical density of the culture at $600 \mathrm{~nm}$ reached 0.6 . The culture was grown for another $10 \mathrm{~h}$ at $25^{\circ} \mathrm{C}$ with shaking at $200 \mathrm{rpm}$ [13].

Recombinant E. coli BL21 (DE3) cells were disrupted by sonication, and centrifuged at $12,000 \times g$ at $4{ }^{\circ} \mathrm{C}$ for $30 \mathrm{~min}$ to remove cell debris. The supernatant obtained $(200 \mathrm{~mL})$ was loaded onto a Ni-NTA agarose column $(1 \times 5 \mathrm{~cm})$. The column was eluted with a linear gradient of imidazole $(10-200 \mathrm{mM})$ in $25 \mathrm{mM}$ Tris- $\mathrm{HCl}$ buffer, $\mathrm{pH} 7.5$ [4]. Fractions with pectate lyase activity were collected and dialyzed into 25 mM Tris-HCl buffer (pH 8.0). Recombinant enzyme PpPel10a was analyzed by 10\% SDS-PAGE [39]. The protein concentration was determined using BCA reagent [40].

\subsection{Enzymatic Characterization of Pectate Lyase}

The effect of $\mathrm{pH}$ on the activity of PpPel10a was determined at $\mathrm{pH} 2.0-11.0$ using $0.2 \%$ PGA as the substrate. The reactions were carried out at $50{ }^{\circ} \mathrm{C}$ for $15 \mathrm{~min}$. The effect of $\mathrm{pH}$ on stability was determined by incubating purified recombinant PpPel10a at $4{ }^{\circ} \mathrm{C}$ for $24 \mathrm{~h}$ at different $\mathrm{pH}$, then the enzyme activity was assayed in standard conditions $\left(50{ }^{\circ} \mathrm{C}, 15 \mathrm{~min}\right)$. The buffers used in this study were: $\mathrm{pH}$ 2.0-6.0, $50 \mathrm{mM}$ sodium acetate buffer; $\mathrm{pH}$ 6.0-8.0, $50 \mathrm{mM}$ phosphate buffer; $\mathrm{pH}$ 8.0-11.0, $50 \mathrm{mM}$ sodium glycine buffer. The effect of temperature on enzyme activity was studied at $20-80{ }^{\circ} \mathrm{C}$ at $\mathrm{pH} 9.0$ for $15 \mathrm{~min}$. Thermostability of PpPel10a was studied by measuring residual pectate lyase activity after preincubating the enzyme at different temperatures for up to $1 \mathrm{~h} \mathrm{[41].} \mathrm{Then,} \mathrm{the} \mathrm{residual}$ activities were determined at $\mathrm{pH} 9.0,50{ }^{\circ} \mathrm{C}$, over $15 \mathrm{~min}$.

The effects of metal ions or chemical compounds ( 1 and $5 \mathrm{mM}$ ) on pectate lyase activity were measured by preincubation of PpPel10a in different metal ion solutions or chemicals at $4{ }^{\circ} \mathrm{C}$ for $24 \mathrm{~h}$. Then, the residual activities were measured using $0.2 \% \mathrm{PGA}$ as the substrate at $\mathrm{pH} 9.0$ and $50{ }^{\circ} \mathrm{C}$ for $15 \mathrm{~min}$ [13]. Enzyme without preincubation was defined as $100 \%$ active. The effect of $\mathrm{Ca}^{2+}$ on pectate lyase activity was determined from 0.1 to $5 \mathrm{mM} \mathrm{Ca}^{2+}$. The enzymatic reaction without the addition of $\mathrm{Ca}^{2+}$ was set as $100 \%$ activity. The kinetic parameters of PpPel10a were measured using 0.1-5.0 mg/mL PGA in standard assay conditions ( $\mathrm{pH} 9.0,50{ }^{\circ} \mathrm{C}, 15 \mathrm{~min}$ ). Kinetic values $\mathrm{K}_{\mathrm{m}}, \mathrm{v}_{\max }$ and $\mathrm{k}_{\mathrm{cat}}$ were calculated from Lineweaver-Burk plots [42].

\subsection{Analysis of Lytic Products from Citrus Pectin on Degradation by PpPel10a}

The change of molecular weight of citrus pectin after treatment with PpPel10a was analyzed by HPGPC using a TSK-gel G-3000PWXL column $(7.8 \times 300 \mathrm{~mm}$; Tosoh, Tokyo, Japan) [43]. The column was calibrated with standard dextrans $(1,5,12,25$ and $50 \mathrm{kDa})$ (Sigma-Aldrich, St. Louis, MO, USA). The unsaturated galacturonic acids released from citrus pectin by PpPel10a were analyzed by HPAEC with a pulsed amperometric detector [44]. The unsaturated galacturonic acids were identified by ESI-MS with the amaZon speed ion ETD trap (Bruker, Bremen, Germany) using negative electrospray as the ionization process [45].

\subsection{Application of PpPel10a in Viscosity Reduction and Ramie Degumming}

Purified PpPel10a $(1.0 \mathrm{U})$ and PGA $(0.2 \% w / v)$ were incubated in $10 \mathrm{~mL}$ of $50 \mathrm{mM}$ sodium glycine buffer ( $\mathrm{pH} 9.0$ ) at $50^{\circ} \mathrm{C}$ for up to $1 \mathrm{~h}$. Viscosity was determined using a glass capillary viscometer (1833, Shenyi Glass, Shanghai, China) at timed intervals [24,46]. The viscosity of PGA without enzymatic treatment was considered as $100 \%$. The extent of PGA cleavage was determined by measuring the released reducing sugars using the DNS method $[46,47]$.

For ramie degumming, $2 \mathrm{~g}$ of ramie fibers were boiled in distilled water for $10 \mathrm{~min}$, then treated by chemical $(0.5 \%$ or $1 \% \mathrm{NaOH})$, enzyme $(1 \mathrm{U} / \mathrm{mL}$ purified recombinant PpPel10a), or a chemical-enzyme combination $(1 \mathrm{U} / \mathrm{mL}$ purified recombinant PpPel10a in $0.5 \%$ sodium hydroxide) in $20 \mathrm{~mL}$ of $50 \mathrm{mM}$ sodium glycine buffer ( $\mathrm{pH}$ 9.0). The mixtures were shaken at $50{ }^{\circ} \mathrm{C}$ and $100 \mathrm{rpm}$ for $4 \mathrm{~h}$. Then, the ramie fibers were washed twice and dried to constant weight. The weight loss was recorded, and the surface of the ramie fibers was observed by SEM $[10,11,13]$. Ramie fibers treated with $50 \mathrm{mM}$ sodium glycine 
buffer ( $\mathrm{pH}$ 9.0) were used as the negative control. The experiments were performed with five parallels. For ramie degumming, the activity and stability of PpPel10a in the chemical-enzyme combination treatment $(0.5 \% \mathrm{NaOH}$ in $20 \mathrm{~mL}$ of $50 \mathrm{mM}$ sodium glycine buffer, $\mathrm{pH} 9.0)$ was studied using $0.2 \%$ PGA as the substrate.

\section{Conclusions}

An alkaline pectate lyase was screened from P. polymyxa KF-1 and identified as belonging to PL family 10. The enzyme showed catalytic activity toward citrus pectin, producing unsaturated mono- and oligogalacturonates. The significant weight loss of ramie fibers treated with PpPel10a indicated the potential of this enzyme for application in ramie degumming. PpPel10a, which has good thermostability and $\mathrm{pH}$ stability, might be suitable for use in the textile industry.

Supplementary Materials: The following are available online, Figure S1: Measurement of P. polymyxa KF-1 pectate lyase activity during liquid culture, Figure S2: Structural model of PpPel10a generated by SWISS-MODEL using pectate lyase from $C$. cellulosa (PDB ID: $1 G X N$, identity $=44.79 \%$ ) as the template.

Author Contributions: Conceptualization, J.G.; Data curation, Y.Z. and Y.Y.; Formal analysis, X.Z. and Y.L.; Funding acquisition, Q.L.; Methodology, Y.Z. and Y.Y.; Software, Y.Z., Y.Y. and J.G.; Validation, Y.Z.; Visualization, X.Z.; Writing-Original draft, Y.Z. and J.G.; Writing—Review \& editing, J.G.

Funding: We thank the Natural Science Foundation of China $(31770852,31400299)$ for supporting this study.

Conflicts of Interest: The authors declare no conflict of interest.

\section{References}

1. Wikiera, A.; Irla, M.; Mika, M. Health-promoting properties of pectin. Postepy Hig. Med. Dosw. (Online) 2014, 68, 590-596. [CrossRef] [PubMed]

2. Chen, J.; Liu, W.; Liu, C.M.; Li, T.; Liang, R.H.; Luo, S.J. Pectin modifications: A review. Crit. Rev. Food Sci. Nutr. 2015, 55, 1684-1698. [CrossRef] [PubMed]

3. Wikiera, A.; Mika, M. Structure and properties of pectin. Postepy Biochem. 2013, 59, 89-94. [PubMed]

4. Bonnin, E.; Garnier, C.; Ralet, M.C. Pectin-modifying enzymes and pectin-derived materials: Applications and impacts. Appl. Microbiol. Biotechnol. 2014, 98, 519-532. [CrossRef] [PubMed]

5. Sriamornsak, P. Application of pectin in oral drug delivery. Expert Opin. Drug Deliv. 2011, 8, $1009-1023$. [CrossRef] [PubMed]

6. Hugouvieux-Cotte-Pattat, N.; Condemine, G.; Shevchik, V.E. Bacterial pectate lyases, structural and functional diversity. Environ. Microbiol. Rep. 2014, 6, 427-440. [CrossRef] [PubMed]

7. Marín-Rodríguez, M.C.; Orchard, J.; Seymour, G.B. Pectate lyases, cell wall degradation and fruit softening. J. Exp. Bot. 2002, 53, 2115-2119. [CrossRef] [PubMed]

8. Sutherland, I.W. Polysaccharide lyases. FEMS Microbiol. Rev. 1995, 16, 323-347. [CrossRef] [PubMed]

9. Kian, L.K.; Saba, N.; Jawaid, M.; Sultan, M.T.H. A review on processing techniques of bast fibers nanocellulose and its polylactic acid (PLA) nanocomposites. Int. J. Biol. Macromol. 2018, in press. [CrossRef] [PubMed]

10. Mukhopadhyay, A.; Dutta, N.; Chattopadhyay, D.; Chakrabarti, K. Degumming of ramie fiber and the production of reducing sugars from waste peels using nanoparticle supplemented pectate lyase. Bioresour. Technol. 2013, 137, 202-208. [CrossRef] [PubMed]

11. Basu, S.; Saha, M.N.; Chattopadhyay, D.; Chakrabarti, K. Degumming and characterization of ramie fibre using pectate lyase from immobilized Bacillus pumilus DKS1. Lett. Appl. Microbiol. 2009, 48, 593-597. [CrossRef] [PubMed]

12. Zhou, Z.; Liu, Y.; Chang, Z.; Wang, H.; Leier, A.; Marquez-Lago, T.T.; Ma, Y.; Li, J.; Song, J. Structure-based engineering of a pectate lyase with improved specific activity for ramie degumming. Appl. Microbiol. Biotechnol. 2017, 101, 2919-2929. [CrossRef] [PubMed]

13. Zhang, C.; Yao, J.; Zhou, C.; Mao, L.; Zhang, G.; Ma, Y. The alkaline pectate lyase PEL168 of Bacillus subtilis heterologously expressed in Pichia pastoris is more stable and efficient for degumming ramie fiber. BMC Biotechnol. 2013, 13, 26. [CrossRef] [PubMed] 
14. Berensmeier, S.; Singh, S.A.; Meens, J.; Buchholz, K. Cloning of the pelA gene from Bacillus licheniformis 14A and biochemical characterization of recombinant, thermostable, high-alkaline pectate lyase. Appl. Microbiol. Biotechnol. 2004, 64, 560-567. [CrossRef] [PubMed]

15. Liu, Y.; Chen, G.; Wang, J.; Hao, Y.; Li, M.; Li, Y.; Hu, B.; Lu, F. Efficient expression of an alkaline pectate lyase gene from Bacillus subtilis and the characterization of the recombinant protein. Biotechnol. Lett. 2012, 34, 109-115. [CrossRef] [PubMed]

16. Sukhumsiirchart, W.; Kawanishi, S.; Deesukon, W.; Chansiri, K.; Kawasaki, H.; Sakamoto, T. Purification, characterization, and overexpression of thermophilic pectate lyase of Bacillus sp. RN1 isolated from a hot spring in Thailand. Biosci. Biotechnol. Biochem. 2009, 73, 268-273. [CrossRef] [PubMed]

17. Chiliveri, S.R.; Linga, V.R. A novel thermostable, alkaline pectate lyase from Bacillus tequilensis SV11 with potential in textile industry. Carbohydr. Polym. 2014, 111, 264-272. [CrossRef] [PubMed]

18. Zheng, Y.; Huang, C.H.; Liu, W.; Ko, T.P.; Xue, Y.; Zhou, C.; Guo, R.T.; Ma, Y. Crystal structure and substrate-binding mode of a novel pectate lyase from alkaliphilic Bacillus sp. N16-5. Biochem. Biophys. Res. Commun. 2012, 420, 269-274. [CrossRef] [PubMed]

19. Lombard, V.; Golaconda Ramulu, H.; Drula, E.; Coutinho, P.M.; Henrissat, B. The carbohydrate-active enzymes database (CAZy) in 2013. Nucleic. Acids Res. 2014, 42, D490-D495. [CrossRef] [PubMed]

20. Zhai, C.; Cao, J.; Wang, Y. Cloning and expression of a pectate lyase gene from Bacillus alcalophillus NTT33. Enzyme Microb. Technol. 2003, 33, 173-178. [CrossRef]

21. Sawada, K.; Ogawa, A.; Ozawa, T.; Sumitomo, N.; Hatada, Y.; Kobayashi, T.; Ito, S. Nucleotide and amino-acid sequences of a new-type pectate lyase from an alkaliphilic strain of Bacillus. Eur. J. Biochem. 2000, 267, 1510-1515. [CrossRef] [PubMed]

22. Bekri, M.A.; Desair, J.; Keijers, V.; Proost, P.; Searle-van Leeuwen, M.; Vanderleyden, J.; Vande Broek, A. Azospirillum irakense produces a novel type of pectate lyase. J. Bacteriol. 1999, 181, 2440-2447. [PubMed]

23. Walker, S.G.; Ryan, M.E. Cloning and expression of a pectate lyase from the oral spirochete Treponema pectinovorum ATCC 33768. FEMS Microbiol. Lett. 2003, 226, 385-390. [CrossRef]

24. Yuan, P.; Meng, K.; Wang, Y.; Luo, H.; Shi, P.; Huang, H.; Tu, T.; Yang, P.; Yao, B. A low-temperature-active alkaline pectate lyase from Xanthomonas campestris ACCC 10048 with high activity over a wide $\mathrm{pH}$ range. Appl. Biochem. Biotechnol. 2012, 168, 1489-1500. [CrossRef] [PubMed]

25. Petersen, T.N.; Brunak, S.; von Heijne, G.; Nielsen, H. SignalP 4.0: Discriminating signal peptides from transmembrane regions. Nat. Methods 2011, 8, 785-786. [CrossRef] [PubMed]

26. Wilkins, M.R.; Gasteiger, E.; Bairoch, A.; Sanchez, J.C.; Williams, K.L.; Appel, R.D.; Hochstrasser, D.F. Protein identification and analysis tools in the ExPASy server. Methods Mol. Biol. 1999, 112, 531-552. [PubMed]

27. Charnock, S.J.; Brown, I.E.; Turkenburg, J.P.; Black, G.W.; Davies, G.J. Convergent evolution sheds light on the anti-beta-elimination mechanism common to family 1 and 10 polysaccharide lyases. Proc. Natl. Acad. Sci. USA 2002, 99, 12067-12072. [CrossRef] [PubMed]

28. Alahuhta, M.; Chandrayan, P.; Kataeva, I.; Adams, M.W.; Himmel, M.E.; Lunin, V.V. A 1.5 Å resolution X-ray structure of the catalytic module of Caldicellulosiruptor bescii family 3 pectate lyase. Acta Crystallogr. Sect. F Struct. Biol. Cryst. Commun. 2011, 67, 1498-1500. [CrossRef] [PubMed]

29. Yuan, P.; Meng, K.; Shi, P.; Luo, H.; Huang, H.; Tu, T.; Yang, P.; Yao, B. An alkaline-active and alkali-stable pectate lyase from Streptomyces sp. S27 with potential in textile industry. J. Ind. Microbiol. Biotechnol. 2012, 39, 909-915. [CrossRef] [PubMed]

30. Li, Z.; Bai, Z.; Zhang, B.; Li, B.; Jin, B.; Zhang, M.; Lin, F.; Zhang, H. Purification and characterization of alkaline pectin lyase from a newly isolated Bacillus clausii and its application in elicitation of plant disease resistance. Appl. Biochem. Biotechnol. 2012, 167, 2241-2256. [CrossRef] [PubMed]

31. Wang, M.H.; Kim, J.G.; Ahn, S.E.; Lee, A.Y.; Bae, T.M.; Kim, D.R.; Hwang, Y.S. Potential role of pectate lyase and $\mathrm{Ca}\left({ }^{2+}\right)$ in the increase in strawberry fruit firmness induced by short-term treatment with high-pressure $\mathrm{CO}_{2}$. J. Food Sci. 2014, 79, S685-S692. [CrossRef] [PubMed]

32. Basu, S.; Roy, A.; Ghosh, A.; Bera, A.; Chattopadhyay, D.; Chakrabarti, K. Arg ${ }^{235}$ is an essential catalytic residue of Bacillus pumilus DKS1 pectate lyase to degum ramie fibre. Biodegradation 2011, 22, 153-161. [CrossRef] [PubMed]

33. Shi, A.; Hu, H.; Zheng, F.; Long, L.; Ding, S. Biochemical characteristics of an alkaline pectate lyase PelA from Volvariella volvacea: Roles of the highly conserved N-glycosylation site in its secretion and activity. Appl. Microbiol. Biotechnol. 2015, 99, 3447-3458. [CrossRef] [PubMed] 
34. Shahid, M.; Kim, M.; Yeon, A.; Andres, A.M.; You, S.; Kim, J. Quantitative Proteomic Analysis Reveals Caffeine-Perturbed Proteomic Profiles in Normal Bladder Epithelial Cells. Proteomics 2018, 19, e1800190. [CrossRef] [PubMed]

35. Tyanova, S.; Temu, T.; Carlson, A.; Sinitcyn, P.; Mann, M.; Cox, J. Visualization of LC-MS/MS proteomics data in MaxQuant. Proteomics 2015, 15, 1453-1456. [CrossRef] [PubMed]

36. Hall, B.G. Building phylogenetic trees from molecular data with MEGA. Mol. Biol. Evol. 2013, 30, 1229-1235. [CrossRef] [PubMed]

37. Biasini, M.; Bienert, S.; Waterhouse, A.; Arnold, K.; Studer, G.; Schmidt, T.; Kiefer, F.; Gallo Cassarino, T.; Bertoni, M.; Bordoli, L.; et al. SWISS-MODEL: Modelling protein tertiary and quaternary structure using evolutionary information. Nucleic Acids Res. 2014, 42, W252-W258. [CrossRef] [PubMed]

38. Lessard, J.C. Molecular cloning. Methods Enzymol. 2013, 529, 85-98. [CrossRef] [PubMed]

39. Brunelle, J.L.; Green, R. One-dimensional SDS-polyacrylamide gel electrophoresis (1D SDS-PAGE). Methods Enzymol. 2014, 541, 151-159. [CrossRef] [PubMed]

40. Walker, J.M. The bicinchoninic acid (BCA) assay for protein quantitation. Methods Mol. Biol. 1994, 32, 5-8. [PubMed]

41. Hugues, M.; Boivin, P.; Gauillard, F.; Nicolas, J.; Thiry, J.M.; Richard-Forget, F. Two lipoxygenases from germinated barley-heat and kilning stability. J. Food Sci. 1994, 59, 885-889. [CrossRef]

42. Ghim, Y.S.; Chang, H.N. Diffusional falsification of kinetic constants on Lineweaver-Burk plots. J. Theor. Biol. 1983, 105, 91-102. [CrossRef]

43. Wu, D.; Cui, L.; Yang, G.; Ning, X.; Sun, L.; Zhou, Y. Preparing rhamnogalacturonan II domains from seven plant pectins using Penicillium oxalicum degradation and their structural comparison. Carbohydr. Polym. 2018, 180, 209-215. [CrossRef] [PubMed]

44. Hu, Y.; Yan, X.; Zhang, H.; Liu, J.; Luo, F.; Cui, Y.; Wang, W.; Zhou, Y. Cloning and expression of a novel alpha-1,3-arabinofuranosidase from Penicillium oxalicum sp. 68. AMB Express 2018, 8, 51. [CrossRef] [PubMed]

45. Rudolf, F.; Friedrich, A. Reductive Alkaline Release of N-Glycans Generates a Variety of Unexpected, Useful Products. Proteomics 2018, 18. [CrossRef]

46. Li, G.; Rao, L.; Xue, Y.; Zhou, C.; Zhang, Y.; Ma, Y. Cloning, expression, and characterization of a highly active alkaline pectate lyase from alkaliphilic Bacillus sp. N16-5. J. Microbiol. Biotechnol. 2010, 20, 670-677. [CrossRef] [PubMed]

47. McCleary, B.V.; McGeough, P. A Comparison of Polysaccharide Substrates and Reducing Sugar Methods for the Measurement of endo-1,4-beta-Xylanase. Appl. Biochem. Biotechnol. 2015, 177, 1152-1163. [CrossRef] [PubMed]

Sample Availability: Not available.

(C) 2018 by the authors. Licensee MDPI, Basel, Switzerland. This article is an open access article distributed under the terms and conditions of the Creative Commons Attribution (CC BY) license (http:/ / creativecommons.org/licenses/by/4.0/). 